Published in final edited form as:

Prog Brain Res. 2014 ; 211: 235-254. doi:10.1016/B978-0-444-63425-2.00010-6.

\title{
The Role of Dopamine in Huntington's Disease
}

\author{
Carlos Cepeda ${ }^{1}$, Kerry P. S. Murphy ${ }^{2}$, Martin Parent ${ }^{3}$, and Michael S. Levine ${ }^{1}$ \\ ${ }^{1}$ Intellectual and Developmental Disabilities Research Center, Semel Institute for Neuroscience \\ and Human Behavior, David Geffen School of Medicine, University of California Los Angeles, \\ USA
}

2Huntington's Disease Research Forum, Department of Life Sciences, The Open University, Milton Keynes, UK

${ }^{3}$ Centre de Recherche de l'Institut Universitaire en Santé Mentale de Québec, Department of Psychiatry and Neuroscience, Faculty of Medicine, Université Laval, Quebec City, QC, Canada

\section{Abstract}

Alterations in dopamine (DA) neurotransmission in Parkinson's disease are well-known and widely studied. Much less is known about DA changes that accompany and underlie some of the symptoms of Huntington's disease (HD), a dominant inherited neurodegenerative disorder characterized by chorea, cognitive deficits and psychiatric disturbances. The cause is an expansion in CAG (glutamine) repeats in the HTT gene. The principal histopathology of HD is the loss of medium-sized spiny neurons (MSNs) and, to a lesser degree, neuronal loss in cerebral cortex, thalamus, hippocampus and hypothalamus. Neurochemical, electrophysiological and behavioral studies in HD patients and genetic mouse models suggest biphasic changes in DA neurotransmission. In the early stages DA neurotransmission is increased leading to hyperkinetic movements that can be alleviated by depleting DA stores. In contrast, in the late stages DA deficits produce hypokinesia that can be treated by increasing DA function. Alterations in DA neurotransmission affect glutamate receptor modulation and could contribute to excitotoxicity. The mechanisms of DA dysfunction, in particular the increased DA tone in the early stages of the disease, are presently unknown but may include initial upregulation of DA neuron activity caused by the genetic mutation, reduced inhibition resulting from striatal MSN loss, increased excitation from cortical inputs, and DA autoreceptor dysfunction. Targeting both DA and glutamate receptor dysfunction could be the best strategy to treat HD symptoms.

\section{Keywords}

Huntington's disease; dopamine; neurotransmission; receptors; glutamate; medium-sized spiny neurons

Correspondence: Michael S. Levine, PhD, IDDRC Room 58-258, Semel Institute for Neuroscience and Human Behavior, UCLA School of Medicine, 760 Westwood Plaza, Los Angeles, CA 90095, Tel: (310) 825-7595, Fax: (310) 206-5060, 


\section{Introduction}

Huntington's disease (HD) is a fatal, slowly progressing neurodegenerative disease caused by a mutation in the HTT gene. The symptoms of HD include chorea (uncontrollable dancelike movements), cognitive deficits and mood changes. Histopathologically, there is massive loss of striatal medium-sized spiny neurons (MSNs) and, to a lesser degree, cortical pyramidal neurons. The mechanisms of cell loss remain unclear but may involve excess glutamate release from cortical and thalamic terminals, increased sensitivity of glutamate receptors, and increased activation of pro-apoptotic extrasynaptic N-methyl-D-aspartate (NMDA) receptors. Alterations in dopamine (DA) function and neurotransmission have a significant role in the motor and cognitive symptoms of HD since it is well-known that glutamate receptor function is modulated by activation of DA receptors. In this chapter we discuss changes in DA neurotransmission that may underlie some of the electrophysiological, neuropathological, behavioral and cognitive alterations in HD. Based on clinical and experimental data we propose that the modulatory function of DA is disrupted early in disease progression, leading to aberrant glutamate transmission and consequent excitotoxic cascades. We also discuss possible mechanisms of altered DA modulation and the search for rational therapies based on these findings.

\section{Striatal DA Innervation in the HD Postmortem Brain}

Neuropathological alterations that characterize HD are widespread but predominantly affect the striatum and the cerebral cortex. The massive atrophy of the striatum is the major pathological hallmark (Vonsattel et al., 1985) and is largely caused by the loss of MSNs, the interneurons being relatively well preserved (Graveland et al., 1985; Ferrante et al., 1987; Kowall et al., 1987; Massouh et al., 2008; Vonsattel et al., 2008a), except for parvalbumin interneurons (Reiner et al., 2013). These changes contribute to the expression of HD symptoms that include hyperkinesia and choreiform involuntary movements in the early stages, as well as rigidity, hypokinesia and debilitating psychiatric symptoms in the later stages (Phillips et al., 2008).

In a pioneering neuropathological study, Bernheimer and colleagues reported no significant cell loss in the substantia nigra of HD patients (Bernheimer et al., 1973). However, by using more appropriate stereological procedures that accounted for substantia nigra atrophy occurring in this neurodegenerative disease (Gibb, 1991; Vonsattel et al., 2008b), other investigators reported a significant decrease in the number of substantia nigra neurons in HD brains (Oyanagi et al., 1989; Richardson, 1990). Interestingly, recent evidence has suggested that changes in chemical content of monoaminergic neurons might occur in the dorsal raphe nucleus, leading to an increase of DA neurons at the expense of serotonin neurons (Jahanshahi et al., 2013). Such a phenotypic shift has to be taken into account to understand the neuropathological and neuroadaptive mechanisms in HD.

Post-mortem studies of HD brains and age-matched controls reveal a significant decrease of tyrosine hydroxylase $(\mathrm{TH})$ immunoreactivity accompanied by a diminution in the density of $\mathrm{TH}$ axon terminals throughout the entire extent of the striatum in advanced HD patients (Bedard et al., 2011). This change appears to be more significant in the caudate nucleus, 
followed by the putamen and the nucleus accumbens. It is believed that the reported striatal DA innervation decrease might significantly contribute to the rigidity and akinesia displayed by advanced HD patients, a motor impairment that strikingly resembles Parkinson's disease. These post-mortem observations are in keeping with other preliminary studies suggesting nigrostriatal DA system impairment in advanced HD (Ferrante and Kowall, 1987; Ginovart et al., 1997; Bohnen et al., 2000; Suzuki et al., 2001; Yohrling et al., 2003).

Besides the overall decrease of TH immunoreactivity in the striatum of HD brains (Bedard et al., 2011), an intense and well-delineated TH-immunoreactive zone lying along the ventricular border of the caudate nucleus has recently been described (Bedard et al., 2010; Parent et al., 2013). The small and densely packed DA axons found in this restricted striatal area overlap the deep layers of the subventricular zone, one of the rare brain areas that has retained the possibility to generate new neurons throughout life. The marked increase in the size of the subventricular zone reported in HD (Curtis et al., 2007) contrasts strikingly with the severe cell loss and atrophy that occurs in the adjoining portion of the striatum. Indeed, the close proximity of the subventricular zone with the striatum makes it a potential source of endogenous neurons that could be engaged in brain repair strategies for this neurodegenerative disease. The dense DA innervation of the subventricular zone observed in HD brains indicates that this monoamine, known to exert a robust excitatory influence upon adult neurogenesis (Baker et al., 2004; Hoglinger et al., 2004; Van Kampen et al., 2004; Lao et al., 2013), might significantly contribute to cell proliferation in HD and could have a crucial role in intrinsic mechanisms involved in attempts to produce new neurons in order to compensate for the massive striatal neuronal losses that occur. It could also play a role in striatal gliogenesis that takes place in such a pathological condition (Sapp et al., 2001).

Evidence for the presence of DA neurons intrinsic to the striatum was obtained in various species, including humans (Porritt et al., 2000; Prensa et al., 2000; Cossette et al., 2004; Cossette et al., 2005b; Cossette et al., 2005a; Huot and Parent, 2007). Immunhistochemical studies indicate that the vast majority of TH positive striatal interneurons also express the enzyme glutamic acid decarboxylase (GAD) suggesting that they might represent a particular subtype of GABA producing neurons (Cossette et al., 2005a). In healthy brains, these neurons were reported to be more abundant in the ventral striatum and occurred in larger number in the putamen than in the caudate nucleus (Cossette et al., 2005b; Huot and Parent, 2007). In the striatum of HD brains, very few of these TH interneurons were observed compared to age-matched controls (Huot et al., 2007). Whether this specific type of striatal interneuron degenerates, as it is the case for parvalbumin interneurons (Reiner et al., 2013), or undergoes a phenotypic shift is presently unknown. Although they have been shown to act through fast GABAergic synaptic transmission in transgenic mice (IbanezSandoval et al., 2010), these TH positive interneurons might also play a significant role in impairments in DA transmission reported in HD.

\section{Neurochemistry}

The idea that aberrant DA signaling underlies behavioral abnormalities in HD was first proposed as a predictive test when asymptomatic offspring of affected individuals developed dyskinesias in response to levodopa (L-DOPA) administration (Klawans et al., 1970). The 
hypothesis was that stimulation of DA receptors was involved in the production of dyskinesias as a basic mechanism of chorea. In support, studies in HD patients demonstrated that increased DA release induces chorea while a reduction in DA leads to akinesia (Bird, 1980). Other studies indicating an involvement of the DA nigrostriatal pathway in HD demonstrated increased levels of DA in postmortem brains of HD patients and showed that DA-depleting agents, such as tetrabenazine (TBZ), can be used with therapeutic benefit (Bird, 1980).

Early post-mortem biochemical measurements of DA concentrations in HD patients yielded inconsistent results. The first biochemical attempts to determine the level of DA markers in autopsied HD brains led to the conclusion that it was unchanged (Bernheimer et al., 1973; Bird and Iversen, 1974; McGeer and McGeer, 1976) or increased (Bird et al., 1980; Spokes, 1980) in the striatum. However, later neurochemical studies of HD patients suggested that increased DA occurs in the early stages of the disease (Garrett and Soares-da-Silva, 1992) while postmortem studies of late-stage HD patients showed reduced levels of caudate DA and homovanillic acid, the principal DA metabolite (Kish et al., 1987). Thus, it was thought that DA levels in HD may show biphasic, time-dependent changes, with early increases followed by late decreases associated with biphasic movement symptoms of early (chorea) and late (akinesia) HD.

The impairment of the nigrostriatal DA system in advanced HD was supported by PET studies in which various DA markers can be imaged in the brains of living patients. These studies indicated a significant decrease in the binding of the DA transporter (DAT) (Ginovart et al., 1997) and vesicular monoamine transporter 2 (VMAT2) (Bohnen et al., 2000 ) in the striatum. These findings can be interpreted as indications of a loss of DA striatal innervation in HD, which appears to be particularly severe in patients suffering from the rigid-akinetic variant (Bohnen et al., 2000). More direct proofs of striatal losses of DAT and VMAT2 could be obtained by means of autoradiographic binding studies in autopsied HD brains (Suzuki et al., 2001).

\section{DA Receptors}

Studies using positron emission tomography, autoradiography, and markers for pre- and postsynaptic markers demonstrated reduced striatal DA D1 and D2 receptor density, even in asymptomatic HD patients, further indicating that DA signaling is disrupted early in HD (Richfield et al., 1991; van Oostrom et al., 2009). These observations were confirmed by imaging studies, which reported reduced striatal D1 and D2 receptors in both HD patients and asymptomatic HD mutation carriers (Weeks et al., 1996). Striatal and cortical loss of DA receptors in presymptomatic and early stage HD patients has been correlated with early cognitive decline, which may reflect altered synaptic plasticity and lead to deficits in cognitive processes such as attention, executive function, learning, and memory (Backman and Farde, 2001).

\section{DA in Genetic Animal Models of HD}

The generation of genetic rodent models of HD has permitted examination of mechanisms during disease progression. The most widely used mouse model of HD is the R6/2 line, a 
fragment transgenic mouse expressing exon 1 of $H T T$ with $~ 150$ CAG repeats (Mangiarini et al., 1996). R6/2 mice display a very rapidly progressing phenotype, similar to the juvenile form of HD in humans. In these mice, overt symptoms begin to appear at 5-7 weeks of age and become fully manifest after 8 weeks. HD mouse models with full-length mutant $H T T$ include the yeast artificial chromosome model with 128 CAG repeats (YAC128) and the bacterial artificial chromosome model with 97 CAG repeats (BACHD) (Slow et al., 2003; Gray et al., 2008). These models show a longer development of the HD phenotype and thus are generally studied at both an early (1.5-2 months of age) and late stage (12 months of age), corresponding roughly to periods of hyperkinesia and hypokinesia, respectively. A transgenic rat model of $\mathrm{HD}$ ( $\operatorname{tgHD}$ ) carries a truncated huntingtin cDNA fragment with 51 CAG repeats (von Horsten et al., 2003).

In agreement with analyses of HD patients, striatal D1 and D2 receptors also are affected in HD mouse models. Striatal D1 and D2 receptor binding is reduced early, with deficits in DA signaling seen in R6/2 mice (Cha et al., 1998; Bibb et al., 2000; Ariano et al., 2002). Significant reductions also are observed in mRNA levels of striatal D1 and D2 receptors in late stage YAC128 mice, but not in BACHD mice (Pouladi et al., 2012). It is unclear why these differences occur between the two full-length models.

There is evidence that DA release is reduced in transgenic mouse models in the late stages of the disease, consistent with what is proposed to occur in human HD. In R6/2 and R6/1 mice, there is a progressive reduction in striatal DA release beginning at 6 weeks of age (Hickey et al., 2002; Petersen et al., 2002; Johnson et al., 2006; Callahan and Abercrombie, 2011), as well as a reduction in homovanillic acid in symptomatic stages concomitant with motor abnormalities (Mochel et al., 2011). Deficits in DA levels and/or release have been attributed to either impaired vesicle loading or a reduction in DA reserve pool vesicles available for mobilization (Ortiz et al., 2010). The tgHD rat model displays an increase in striatal DA levels and DA neurons at the early symptomatic stage in two main sources of telencephalic DA input, the substantia nigra pars compacta and ventral tegmental area (Jahanshahi et al., 2010). However, these rats also show impaired DA release dynamics, as demonstrated by a reduction in evoked release of DA (Ortiz et al., 2012). Since these results from animal models are not entirely consistent, future studies of DA release dynamics in HD will be necessary to determine the changes in DA levels that occur in the early and late disease stages.

\section{Synaptic Electrophysiology in HD Models}

Electrophysiological studies in genetic mouse models have suggested biphasic changes in glutamate release along the corticostriatal pathway with early increases followed by significant decreases (Cepeda et al., 2003; Joshi et al., 2009) until, in the late stages, there is a major disconnection between cortex and striatum (Cepeda et al., 2007). Alterations in DA receptor modulation of glutamate release also have been demonstrated (Joshi et al., 2009). In particular, age-dependent alterations in corticostriatal activity are paralleled by a decrease in DA D2 receptor modulation at the presynaptic terminal (Joshi et al., 2009), which can be explained by reduced numbers of $\mathrm{D} 2$ receptors. 
The use of enhanced green fluorescent protein to identify striatal direct and indirect pathway MSNs that express DA D1 and D2 receptors, respectively has allowed examination of differential changes in DA modulation of excitatory synaptic inputs to neurons originating these pathways during the course of HD. Studies indicate that, similar to changes in glutamate function, DA tone also follows a biphasic progression with early increases followed by decreases. For example, glutamatergic input to direct pathway MSNs is increased in the early stages of HD in the YAC128 and BACHD mouse models and this input is not modulated by DA. However, modulation is restored by TBZ, supporting an increased DA tone in early HD (André et al., 2011). Thus, contrary to the classic paradigm of basal ganglia function, these recent studies highlight the role of direct pathway neurons in the early symptoms of HD.

\section{DA and Synaptic Plasticity in HD}

In humans, the symptoms of HD, which usually appear in the third to fifth decades of life often include impairment of cognitive function that can lead to dementia (Harper, 1996). The primary sites of neurodegeneration are the striatum (Vonsattel et al., 1985) and cerebral cortex (Vonsattel et al., 1985; Hedreen et al., 1991), and to a lesser extent the hippocampus (Spargo et al., 1993). Several studies have shown that cognitive impairment in both working memory and executive function can occur in gene carriers before the onset of classical symptoms (Foroud et al., 1995; Lawrence et al., 1998; Thiruvady et al., 2007). Post mortem studies (Vonsattel et al., 1985) reveal that the first symptoms (both motor and cognitive) appear in the absence of overt neuronal loss, suggesting that impaired cognition is caused by synaptic and neural dysfunction rather than a consequence of neuronal cell death. Higher cognitive processing involving changes in synaptic weighting in neural networks and alterations in hippocampal synaptic plasticity have been reported in several mouse models of HD (Hodgson et al., 1999; Usdin et al., 1999; Murphy et al., 2000; Gibson et al., 2005). In R6/2 mice, the ability to support long-term potentiation (LTP) at CA1 hippocampal synapses was reduced and this loss of plasticity was apparent prior to the onset of motor symptoms (Murphy et al., 2000), consistent with the view that cognitive disruption precedes motor decline. This view is further supported by the observation that spatial learning is also affected in R6/2 mice and precedes the onset of the motor phenotype (Murphy et al., 2000). The hippocampus is involved in spatial learning and the performance of R6/2 mice in the Morris water maze was found to be impaired; importantly, this behavioral cognitive deficit was also manifest before the onset of an overt motor phenotype (Murphy et al., 2000). The converse of LTP, long-term depression (LTD), is developmentally expressed at hippocampal synapses (Milner et al., 2004), such that it can only be experimentally induced in brain slices prepared from young animals. R6/2 mice exhibited full-blown LTD at all ages examined and failed to show a developmental down-regulation of this phenomenon (Murphy et al., 2000). Longer surviving R6/1 mice (mice with 116 CAG repeats), however, did exhibit a degree of developmental down-regulation, but this was transitory as the ability to support robust LTD re-emerged and persisted once the mice reached maturity (Milnerwood et al., 2006).

While hippocampal studies have been informative and demonstrated that changes in synaptic plasticity occur early in the murine disease phenotype, they do not address directly the cognitive abnormalities observed in human gene carriers nor the role of DA. One of the 
key brain regions involved in the processing of working memory and executive function is the prefrontal cortex (Goldman-Rakic, 1995; Fuster, 2000). Local glutamatergic neuronal networks contribute to the temporary storage and dynamic control of information in this area. Alterations in the properties of these networks affect both working memory and executive function (Goldman-Rakic, 1995). EEG power spectra recorded in the cortex of HD patients are abnormal and the degree of abnormality is correlated with the severity of the cognitive impairment (Bylsma et al., 1994). A similar study examined EEG changes in preclinical gene carriers while performing a working memory task; EEG abnormalities were only apparent during the performance of the task (van der Hiele et al., 2007). Paradoxically, performance on the task was indistinguishable from that of controls, suggesting that alterations in neural network processing precede the development of symptoms. In R6/2 mice, the synchronicity of spike firing in the prefrontal cortex in vivo is reduced, indicating a population-level deficit in network processing (Walker et al., 2008). LTP has been examined in the prefrontal cortex of R6/1 mice in vitro and found to be abnormal. LTP was abolished in symptomatic mice and reduced in mice that were pre-symptomatic (Dallerac et al., 2011). The induction of LTP in the prefrontal cortex and the performance of working memory are both sensitive to the ambient concentration of cortical DA (Williams and Castner, 2006). The induction of LTP is dependent upon co-activation of D1 dopamine receptors and NMDA receptors (Gurden et al., 2000) and the impairment in synaptic plasticity seen in HD mice may be attributable to an alteration in the neuromodulatory properties of midbrain DA inputs that innervate the prefrontal cortex. There is additional evidence supporting the view that abnormal DA signaling may underlie deficits in synaptic function in the prefrontal cortex as a recent study showed that normal LTP can be restored in R6/1 mice in the presence of a D1 dopamine receptor agonist (Dallerac et al., 2011).

Reduced synaptic plasticity appears to be a common deficit in the cortex of HD patients and the neocortex of mouse models of HD. A recent human study, using trans-cranial magnetic stimulation of motor cortex to induce LTD-like changes in motor evoked potentials, showed that both pre-manifest and very early manifest HD patients exhibited a marked reduction in the magnitude of experimentally induced LTD compared with control participants (Orth et al., 2010), validating the predictive power of murine models of neurodegenerative disease. The role of DA in the induction of LTD has also been assessed in vitro in the perirhinal cortex of R6/1 mice (Cummings et al., 2006; Cummings et al., 2007). In these mice, the ageand phenotype-dependent expression of LTD is unusual in that it has a biphasic profile. In pre-symptomatic mice the magnitude of LTD is greater than that seen in age-matched controls whereas in symptomatic mice the ability to support LTD is absent (Cummings et al., 2006). The loss of LTD is also associated with a change in the paired-pulse profile. Instead of exhibiting paired-pulse depression, the profile is shifted to one of paired-pulse facilitation, suggesting a functional loss of neuromodulatory input. The addition of a D2 receptor agonist to the perfusate not only rescued the ability of perirhinal synapses to support LTD but also restored the normal paired-pulse profile (Cummings et al., 2006). DA deficits have also been implicated in the reduction of LTP expressed at corticostriatal synapses in R6/2 mice (Kung et al., 2007). 
In summary, data from human studies show that changes in the properties of cortical neuronal networks are early events in the pathogenesis of HD and the rodent studies indicate, in part, that such network abnormalities are likely to be a consequence of altered DA function.

\section{DA and Excitotoxicity}

Although DA exists in high concentrations in the striatum, studies also suggest a toxic role for DA in which cell death is accelerated through increases in free radical production (Jakel and Maragos, 2000). This has been demonstrated in striatal cultures derived from R6/2 mice, where MSNs undergo DA-mediated oxidative stress and apoptosis (Petersen et al., 2001).

DA and glutamate signaling pathways can synergistically enhance MSN sensitivity to huntingtin toxicity. Studies demonstrate that this deleterious process occurs through D1 but not D2 receptor activation (Tang et al., 2007; Paoletti et al., 2008) and are in agreement with previous studies demonstrating that DA and D1 receptor agonists enhance excitotoxicity (Cepeda et al., 1998; McLaughlin et al., 1998).

D1 receptor-mediated potentiation of NMDA responses, which holds key functional consequences in HD, has been verified in the cortex and striatum (Cepeda et al., 1993; Wang and O'Donnell, 2001; Flores-Hernandez et al., 2002). For example, D1 receptorinduced cell death in MSNs of knock-in HD mice is increased by pretreatment with NMDA when compared with cells from wildtype mice (Paoletti et al., 2008). In neurons from YAC mice or Q111 knock-in mice, the convergence of DA and glutamate signaling pathways leads to $\mathrm{Ca}^{2+}$ overload, resulting in excitotoxic processes such as induction of mitochondrial depolarization and caspase activation (Zeron et al., 2002; Tang et al., 2007; Paoletti et al., 2008).

While D1-NMDA receptor activation is thought to be neurotoxic, activation of D2 receptors reduces NMDA receptor responses and thus may be neuroprotective (Bozzi and Borrelli, 2006). For example, activation of $D 2$ receptors by quinpirole reduces the toxicity of both NMDA and kainic acid in rat striatal neurons (Cepeda et al., 1998), as well as in mesencephalic and cortical neurons (Sawada et al., 1998; Kihara et al., 2002). However, an exclusive role for D1 receptor activation in mediating MSN degeneration is contradicted by evidence that blocking D2 receptor stimulation significantly reverses DA potentiation of mutant huntingtin-induced MSN cell death (Charvin et al., 2005). As cultured striatal neurons can be protected by antagonism of D1 and D2 receptors, it is possible that both D1 and D2 receptor activation might contribute to neurotoxicity (Davis et al., 2002; Bozzi and Borrelli, 2006).

\section{Mechanisms of DA Dysregulation}

Several mechanisms can be invoked to explain alterations in DA neurotransmission. During the early phase of HD, neuropathological studies have shown that discrete islands of neuronal loss and astrocytosis appear in the striosomes almost exclusively, whereas in the late phase, cell loss increasingly occurs in the matrix compartment (Hedreen and Folstein, 1995). As MSNs from the striosomes project to the substantia nigra pars compacta, it may 
be that early degeneration of these inhibitory neurons produces hyperactivity of the DA pathway, contributing to chorea and other early clinical manifestations of HD.

Stimulation of corticostriatal neurons has been shown to activate DA release in the striatum (Nieoullon et al., 1978). In addition, DA neurons that modulate glutamate release in the corticostriatal pathway are subject to afferent glutamate regulation, which is suggested by the presence of glutamate receptors on DA neurons (Meltzer et al., 1997). There is substantial evidence for a direct cortico-nigral projection (Afifi et al., 1974; Kornhuber et al., 1984) and work in rodents demonstrates that this pathway both directly and indirectly regulates the firing pattern of DA neurons (Maurice et al., 1999; Sesack and Carr, 2002). Other studies indicate that stimulation of glutamate receptors on DA neurons increases DA release in both the substantia nigra and in DA innervated areas (Kalivas et al., 1989; Murase et al., 1993). Thus, if DA neuron firing is regulated by frontal cortical neurons, the activity of which is upregulated in early $\mathrm{HD}$, the biphasic trends of DA levels in early and late human HD may be correlated with the biphasic changes of glutamate release by cortical afferents.

\section{DA Agonists and Antagonists as Treatments for HD}

Since the abnormalities in the DA system appear to underlie some of the behavioral symptoms of HD, DA agonists, antagonists, and/or stabilizers may provide potential treatment options. Conceptually, DA stabilizers (or partial agonists) increase or decrease DA receptor activity depending on the level of DA tone. HD patients treated with aripiprazole, a partial D2 receptor agonist, demonstrate improvements in chorea, but not cognitive function (Brusa et al., 2009). A recent phase 3 clinical trial of the DA stabilizer pridopidine demonstrated improvements in hand movements, gait, and balance of HD patients as defined by the unified HD rating scale (de Yebenes et al., 2011). Although these changes fell short of the primary efficacy threshold, the slight improvements in motor dysfunction without any deleterious side effects suggest that treatments targeted towards DA imbalance may have therapeutic benefits.

Current treatment options for HD are limited and confined to antidopaminergic agents for motor symptoms while there are virtually no therapeutics for cognitive deterioration (Venuto et al., 2012). Additionally, clinical results of these treatments seem contradictory, possibly reflecting the dynamic and time-dependent changes that occur in the DA system as the disease progresses (Mochel et al., 2011). For example, both D2 agonists and antagonists have demonstrated clinical benefits for improvement of HD motor symptoms (Tedroff et al., 1999; Haskins and Harrison, 2000; Brusa et al., 2009). Conventional antipsychotic drugs, such as the D2 antagonist haloperidol, are used in clinical practice, but they do not improve functional capacity (Bonelli and Wenning, 2006). Atypical antipsychotic drugs with D2 antagonist properties such as olanzapine, risperidone, quetiapine, and ziprasidone, can improve chorea and impact a larger range of behavioral disturbances with a reduced risk of side effects. D2 agonists also have demonstrated therapeutic potential in HD (Frattola et al., 1977; Caraceni et al., 1980). 
As the early stages of HD may reflect a hyperdopaminergic condition, drugs that reduce DA tone can be beneficial during the choreic movement phase (Mochel et al., 2011). DAdepleting agents, such as TBZ, which inhibit VMAT-2 and decrease DA content in presynaptic vesicles, have been shown to reduce chorea (Huntington Study Group, 2006). Currently, TBZ is the only drug formally approved for treatment of Huntington's chorea by a regulatory agency (Chen et al., 2012; Mestre and Ferreira, 2012).

In vivo and in vitro studies of animal models support a role for DA inhibitors in protecting HD MSNs from cell death. The rationale follows and agrees with experimental and clinical findings suggesting that DA tone is elevated during the early stages of the disease. In YAC128 mice, TBZ alleviates motor deficits and reduces striatal loss in both early and late stages (Tang et al., 2007). TBZ also rescues the increased stereotypies in 1-2 month old YAC128 and BACHD mice (André et al., 2011). The D1 receptor antagonist SCH23390 rescues the changes in excitatory synaptic transmission of direct pathway MSNs that occur in the early symptomatic phase in YAC128 and BACHD mice, suggesting that tonic activation of D1 receptors may underlie early dysfunction of D1 MSNs (André et al., 2011). Similarly, SCH23390 prevents DA/GLU-induced MSN death in YAC128 mice (Tang et al., 2007). In the tgHD rat model, striatal toxicity is reduced by early and chronic treatment with haloperidol (Charvin et al., 2008). However, this evidence is complicated by the fact that haloperidol, a putative D2 receptor antagonist, also modulates NMDA receptor function (Ilyin et al., 1996; Arvanov et al., 1997). Predictably, DA antagonists may be more beneficial when administered with other neuroprotective drugs such as memantine, a NMDA receptor antagonist, as a combination therapy (Wu et al., 2006).

HD mouse models have demonstrated the therapeutic potential of not only DA antagonists, but also DA agonists. For example, in fully symptomatic R6/2 mice, replacement of reduced DA levels by chronic treatment with L-DOPA yields short-term improvements in the HD behavioral phenotype whereas long-term treatment impairs survival and rotarod performance (Hickey et al., 2002). Additionally, as pointed out above the D1 receptor agonist SKF38393 rescues cortical LTP impairment and deficits in synaptic plasticity of R6/1 mice (Dallerac et al., 2011), suggesting that increasing DA levels could improve cognitive dysfunction. Since some treatments may only be suitable early in disease progression, effective therapies need to be temporally oriented to accommodate differential changes in DA function throughout the course of the disease.

\section{Conclusions and Future Directions}

While much knowledge on the role of DA in HD has been gathered in the past few years, many questions remain unanswered and should be the focus of future endeavors. The traditional view that D2 MSNs are more vulnerable in HD is beginning to change due to emerging data from experimental animal models. Based on new evidence, it may be proposed that D1 MSNs should be more vulnerable to the HD mutation, i.e., they become dysfunctional in the early stage of HD and D1-NMDA receptor interactions enhance neurotoxicity. Therefore, the standing question should be reformulated to ask why D1 MSNs are less susceptible to dysfunction in HD. Do they have an intrinsic neuroprotective mechanism that D2 MSNs lack? Recent studies using mice in which D1 or D2 receptor- 
expressing neurons can be identified point in that direction. For example, fluorescenceactivated cell sorting array analyses showed that the transcription factor Zfp521, which is enriched in D1 MSNs, is anti-apoptotic (Lobo et al., 2008). Specifically, Zfp521 promotes proliferation, delays differentiation, and reduces apoptosis (Shen et al., 2011).

Another important issue concerns causes of early perturbations in DA release. Is it the loss of striosome MSN projections to the substantia nigra pars compacta, increased activity along the cortico-nigral projection, or dysregulation of DA release due to loss of D2 autoreceptors? On a similar note, since there are at least two splice variants for D2 receptors, a short D2S (mostly presynaptic) and a long D2L (mostly postsynaptic) form, which one is reduced in early HD? In the striatum, DA D2 auto-receptor function is mediated by synapsin III expression. In brains of R6/2 mice and HD patients, there is a progressive loss of complexins, synaptic proteins similar to syntaxin III that are involved in synaptogenesis and modulate neurotransmitter release (Freeman and Morton, 2004). A similar reduction in synapsin III could explain increased DA transmission in early HD. Thus far, it is unknown whether or not presynaptic D2 auto- or hetero-receptors are lost before postsynaptic receptors (Sandstrom et al., 2010). However, selective agonists of D2 auto-receptors produce long-lasting suppression of extracellular brain DA levels in vivo and could provide promising therapeutic benefits for HD (Pifl et al., 1988). Knowledge of the initial and causative mechanisms of DA receptor dysfunction in HD will certainly lead to better and more rational treatments.

\section{Acknowledgments}

CC and MSL are supported by USPHS NS41574, NS78633, NS81335 and a contract from CHDI Inc.

\section{References}

Afifi AK, Bahuth NB, Kaelber WW, Mikhael E, Nassar S. The cortico-nigral fibre tract. An experimental Fink-Heimer study in cats. J Anat. 1974; 118:469-476. [PubMed: 4141704]

André VM, Cepeda C, Fisher YE, Huynh M, Bardakjian N, Singh S, Yang XW, Levine MS. Differential electrophysiological changes in striatal output neurons in Huntington's disease. J Neurosci. 2011; 31:1170-1182. [PubMed: 21273402]

Ariano MA, Aronin N, Difiglia M, Tagle DA, Sibley DR, Leavitt BR, Hayden MR, Levine MS. Striatal neurochemical changes in transgenic models of Huntington's disease. Journal of neuroscience research. 2002; 68:716-729. [PubMed: 12111832]

Arvanov VL, Liang X, Schwartz J, Grossman S, Wang RY. Clozapine and haloperidol modulate Nmethyl-D-aspartate- and non-N-methyl-D-aspartate receptor-mediated neurotransmission in rat prefrontal cortical neurons in vitro. J Pharmacol Exp Ther. 1997; 283:226-234. [PubMed: 9336328]

Backman L, Farde L. Dopamine and cognitive functioning: brain imaging findings in Huntington's disease and normal aging. Scand J Psychol. 2001; 42:287-296. [PubMed: 11501742]

Baker SA, Baker KA, Hagg T. Dopaminergic nigrostriatal projections regulate neural precursor proliferation in the adult mouse subventricular zone. Eur J Neurosci. 2004; 20:575-579. [PubMed: 15233767]

Bedard C, Wallman MJ, Pourcher E, Parent A, Parent M. Intense dopamine innervation of the subventricular zone in Huntington's disease. Neuroreport. 2010; 21:1074-1079. [PubMed: 20926973]

Bedard C, Wallman MJ, Pourcher E, Gould PV, Parent A, Parent M. Serotonin and dopamine striatal innervation in Parkinson's disease and Huntington's chorea. Parkinsonism Relat Disord. 2011; 17:593-598. [PubMed: 21664855] 
Bernheimer H, Birkmayer W, Hornykiewicz O, Jellinger K, Seitelberger F. Brain dopamine and the syndromes of Parkinson and Huntington. Clinical, morphological and neurochemical correlations. J Neurol Sci. 1973; 20:415-455. [PubMed: 4272516]

Bibb JA, Yan Z, Svenningsson P, Snyder GL, Pieribone VA, Horiuchi A, Nairn AC, Messer A, Greengard P. Severe deficiencies in dopamine signaling in presymptomatic Huntington's disease mice. Proceedings of the National Academy of Sciences of the United States of America. 2000; 97:6809-6814. [PubMed: 10829080]

Bird ED. Chemical pathology of Huntington's disease. Annu Rev Pharmacol Toxicol. 1980; 20:533551. [PubMed: 6446256]

Bird ED, Iversen LL. Huntington's chorea. Post-mortem measurement of glutamic acid decarboxylase, choline acetyltransferase and dopamine in basal ganglia. Brain. 1974; 97:457-472. [PubMed: 4157009]

Bird ED, Spokes EG, Iversen LL. Dopamine and noradrenaline in post-mortem brain in Huntington's disease and schizophrenic illness. Acta Psychiatr Scand Suppl. 1980; 280:63-73. [PubMed: 6447433]

Bohnen NI, Koeppe RA, Meyer P, Ficaro E, Wernette K, Kilbourn MR, Kuhl DE, Frey KA, Albin RL. Decreased striatal monoaminergic terminals in Huntington disease. Neurology. 2000; 54:17531759. [PubMed: 10802780]

Bonelli RM, Wenning GK. Pharmacological management of Huntington's disease: an evidence-based review. Curr Pharm Des. 2006; 12:2701-2720. [PubMed: 16842168]

Bozzi Y, Borrelli E. Dopamine in neurotoxicity and neuroprotection: what do D2 receptors have to do with it? Trends Neurosci. 2006; 29:167-174. [PubMed: 16443286]

Brusa L, Orlacchio A, Moschella V, Iani C, Bernardi G, Mercuri NB. Treatment of the symptoms of Huntington's disease: preliminary results comparing aripiprazole and tetrabenazine. Mov Disord. 2009; 24:126-129. [PubMed: 19170197]

Bylsma FW, Peyser CE, Folstein SE, Folstein MF, Ross C, Brandt J. EEG power spectra in Huntington's disease: clinical and neuropsychological correlates. Neuropsychologia. 1994; 32:137-150. [PubMed: 8190239]

Callahan JW, Abercrombie ED. In vivo Dopamine Efflux is Decreased in Striatum of both Fragment (R6/2) and Full-Length (YAC128) Transgenic Mouse Models of Huntington's Disease. Front Syst Neurosci. 2011; 5:61. [PubMed: 21811446]

Caraceni TA, Girotti F, Giovannini P, Pederzoli M, Parati EA. Effects of DA agonist in Huntington disease hyperkinesia. Ital J Neurol Sci. 1980; 1:155-161. [PubMed: 6210644]

Cepeda C, Buchwald NA, Levine MS. Neuromodulatory actions of dopamine in the neostriatum are dependent upon the excitatory amino acid receptor subtypes activated. Proceedings of the National Academy of Sciences of the United States of America. 1993; 90:9576-9580. [PubMed: 7692449]

Cepeda C, Colwell CS, Itri JN, Chandler SH, Levine MS. Dopaminergic modulation of NMDAinduced whole cell currents in neostriatal neurons in slices: contribution of calcium conductances. Journal of neurophysiology. 1998; 79:82-94. [PubMed: 9425179]

Cepeda C, Wu N, Andre VM, Cummings DM, Levine MS. The corticostriatal pathway in Huntington's disease. Prog Neurobiol. 2007; 81:253-271. [PubMed: 17169479]

Cepeda C, Hurst RS, Calvert CR, Hernandez-Echeagaray E, Nguyen OK, Jocoy E, Christian LJ, Ariano MA, Levine MS. Transient and progressive electrophysiological alterations in the corticostriatal pathway in a mouse model of Huntington's disease. J Neurosci. 2003; 23:961-969. [PubMed: 12574425]

Cha JH, Kosinski CM, Kerner JA, Alsdorf SA, Mangiarini L, Davies SW, Penney JB, Bates GP, Young AB. Altered brain neurotransmitter receptors in transgenic mice expressing a portion of an abnormal human huntington disease gene. Proceedings of the National Academy of Sciences of the United States of America. 1998; 95:6480-6485. [PubMed: 9600992]

Charvin D, Vanhoutte P, Pages C, Borrelli E, Caboche J. Unraveling a role for dopamine in Huntington's disease: the dual role of reactive oxygen species and D2 receptor stimulation. Proceedings of the National Academy of Sciences of the United States of America. 2005; 102:12218-12223. [PubMed: 16103364] 
Charvin D, Roze E, Perrin V, Deyts C, Betuing S, Pages C, Regulier E, Luthi-Carter R, Brouillet E, Deglon N, Caboche J. Haloperidol protects striatal neurons from dysfunction induced by mutated huntingtin in vivo. Neurobiology of disease. 2008; 29:22-29. [PubMed: 17905594]

Chen JJ, Ondo WG, Dashtipour K, Swope DM. Tetrabenazine for the treatment of hyperkinetic movement disorders: a review of the literature. Clinical therapeutics. 2012; 34:1487-1504. [PubMed: 22749259]

Cossette M, Parent A, Levesque D. Tyrosine hydroxylase-positive neurons intrinsic to the human striatum express the transcription factor Nurr1. Eur J Neurosci. 2004; 20:2089-2095. [PubMed: 15450088]

Cossette M, Levesque D, Parent A. Neurochemical characterization of dopaminergic neurons in human striatum. Parkinsonism Relat Disord. 2005a; 11:277-286. [PubMed: 15970454]

Cossette M, Lecomte F, Parent A. Morphology and distribution of dopaminergic neurons intrinsic to the human striatum. J Chem Neuroanat. 2005b; 29:1-11. [PubMed: 15589697]

Cummings DM, Milnerwood AJ, Dallérac GM, Vatsavayai SC, Hirst MC, Murphy KPSJ. Abnormal Cortical Synaptic Plasticity in Mice Transgenic for Exon 1 of the Human Huntington's Disease Mutation. Brain Res Bul. 2007; 72:103-107.

Cummings DM, Milnerwood AJ, Dallerac GM, Waights V, Brown JY, Vatsavayai SC, Hirst MC, Murphy KP. Aberrant cortical synaptic plasticity and dopaminergic dysfunction in a mouse model of huntington's disease. Hum Mol Genet. 2006; 15:2856-2868. [PubMed: 16905556]

Curtis MA, Eriksson PS, Faull RL. Progenitor cells and adult neurogenesis in neurodegenerative diseases and injuries of the basal ganglia. Clin Exp Pharmacol Physiol. 2007; 34:528-532. [PubMed: 17439428]

Dallerac GM, Vatsavayai SC, Cummings DM, Milnerwood AJ, Peddie CJ, Evans KA, Walters SW, Rezaie P, Hirst MC, Murphy KP. Impaired long-term potentiation in the prefrontal cortex of Huntington's disease mouse models: rescue by D1 dopamine receptor activation. Neurodegener Dis. 2011; 8:230-239. [PubMed: 21282937]

Davis S, Brotchie J, Davies I. Protection of striatal neurons by joint blockade of D1 and D2 receptor subtypes in an in vitro model of cerebral hypoxia. Exp Neurol. 2002; 176:229-236. [PubMed: 12093100]

de Yebenes JG, Landwehrmeyer B, Squitieri F, Reilmann R, Rosser A, Barker RA, Saft C, Magnet MK, Sword A, Rembratt A, Tedroff J. Pridopidine for the treatment of motor function in patients with Huntington's disease (MermaiHD): a phase 3, randomised, double-blind, placebo-controlled trial. Lancet Neurol. 2011; 10:1049-1057. [PubMed: 22071279]

Ferrante RJ, Kowall NW. Tyrosine hydroxylase-like immunoreactivity is distributed in the matrix compartment of normal human and Huntington's disease striatum. Brain Res. 1987; 416:141-146. [PubMed: 2887244]

Ferrante RJ, Kowall NW, Beal MF, Martin JB, Bird ED, Richardson EP Jr. Morphologic and histochemical characteristics of a spared subset of striatal neurons in Huntington's disease. J Neuropathol Exp Neurol. 1987; 46:12-27. [PubMed: 2947977]

Flores-Hernandez J, Cepeda C, Hernandez-Echeagaray E, Calvert CR, Jokel ES, Fienberg AA, Greengard P, Levine MS. Dopamine enhancement of NMDA currents in dissociated mediumsized striatal neurons: role of D1 receptors and DARPP-32. Journal of neurophysiology. 2002; 88:3010-3020. [PubMed: 12466426]

Foroud T, Siemers E, Kleindorfer D, Bill DJ, Hodes ME, Norton JA, Conneally PM, Christian JC. Cognitive scores in carriers of Huntington's disease gene compared to noncarriers. Ann Neurol. 1995; 37:657-664. [PubMed: 7755361]

Frattola L, Albiazzati MG, Spano PF, Trabucchi M. Treatment of Huntington's chorea with bromocriptine. Acta Neurol Scand. 1977; 56:37-45. [PubMed: 141860]

Freeman W, Morton AJ. Regional and progressive changes in brain expression of complexin II in a mouse transgenic for the Huntington's disease mutation. Brain Res Bull. 2004; 63:45-55. [PubMed: 15121238]

Fuster JM. Prefrontal neurons in networks of executive memory. Brain Res Bull. 2000; 52:331-336. [PubMed: 10922510] 
Garrett MC, Soares-da-Silva P. Increased cerebrospinal fluid dopamine and 3,4-dihydroxyphenylacetic acid levels in Huntington's disease: evidence for an overactive dopaminergic brain transmission. Journal of neurochemistry. 1992; 58:101-106. [PubMed: 1309230]

Gibb WR. Neuropathology of the substantia nigra. Eur Neurol. 1991; 31(Suppl 1):48-59. [PubMed: 1830274]

Gibson HE, Reim K, Brose N, Morton AJ, Jones S. A similar impairment in CA3 mossy fibre LTP in the R6/2 mouse model of Huntington's disease and in the complexin II knockout mouse. The European journal of neuroscience. 2005; 22:1701-1712. [PubMed: 16197510]

Ginovart N, Lundin A, Farde L, Halldin C, Backman L, Swahn CG, Pauli S, Sedvall G. PET study of the pre- and post-synaptic dopaminergic markers for the neurodegenerative process in Huntington's disease. Brain: a journal of neurology. 1997; 120 (Pt 3):503-514. [PubMed: 9126061]

Goldman-Rakic PS. Cellular basis of working memory. Neuron. 1995; 14:477-485. [PubMed: 7695894]

Graveland GA, Williams RS, DiFiglia M. Evidence for degenerative and regenerative changes in neostriatal spiny neurons in Huntington's disease. Science. 1985; 227:770-773. [PubMed: 3155875]

Gray M, Shirasaki DI, Cepeda C, Andre VM, Wilburn B, Lu XH, Tao J, Yamazaki I, Li SH, Sun YE, Li XJ, Levine MS, Yang XW. Full-length human mutant huntingtin with a stable polyglutamine repeat can elicit progressive and selective neuropathogenesis in BACHD mice. J Neurosci. 2008; 28:6182-6195. [PubMed: 18550760]

Gurden H, Takita M, Jay TM. Essential role of D1 but not D2 receptors in the NMDA receptordependent long-term potentiation at hippocampal-prefrontal cortex synapses in vivo. J Neurosci. 2000; 20:RC106. [PubMed: 11069975]

Harper PS. New genes for old diseases: the molecular basis of myotonic dystrophy and Huntington's disease. The Lumleian Lecture 1995. J R Coll Physicians Lond. 1996; 30:221-231. [PubMed: 8811597]

Haskins BA, Harrison MB. Huntington's Disease. Curr Treat Options Neurol. 2000; 2:243-262. [PubMed: 11096752]

Hedreen JC, Folstein SE. Early loss of neostriatal striosome neurons in Huntington's disease. J Neuropathol Exp Neurol. 1995; 54:105-120. [PubMed: 7815073]

Hedreen JC, Peyser CE, Folstein SE, Ross CA. Neuronal loss in layers V and VI of cerebral cortex in Huntington's disease. Neurosci Lett. 1991; 133:257-261. [PubMed: 1840078]

Hickey MA, Reynolds GP, Morton AJ. The role of dopamine in motor symptoms in the R6/2 transgenic mouse model of Huntington's disease. Journal of neurochemistry. 2002; 81:46-59. [PubMed: 12067237]

Hodgson JG, Agopyan N, Gutekunst CA, Leavitt BR, LePiane F, Singaraja R, Smith DJ, Bissada N, McCutcheon K, Nasir J, Jamot L, Li XJ, Stevens ME, Rosemond E, Roder JC, Phillips AG, Rubin EM, Hersch SM, Hayden MR. A YAC mouse model for Huntington's disease with full-length mutant huntingtin, cytoplasmic toxicity, and selective striatal neurodegeneration. Neuron. 1999; 23:181-192. [PubMed: 10402204]

Hoglinger GU, Rizk P, Muriel MP, Duyckaerts C, Oertel WH, Caille I, Hirsch EC. Dopamine depletion impairs precursor cell proliferation in Parkinson disease. Nat Neurosci. 2004; 7:726735. [PubMed: 15195095]

Huntington Study Group. Tetrabenazine as antichorea therapy in Huntington disease: a randomized controlled trial. Neurology. 2006; 66:366-372. [PubMed: 16476934]

Huot P, Parent A. Dopaminergic neurons intrinsic to the striatum. J Neurochem. 2007; 101:14411447. [PubMed: 17286588]

Huot P, Levesque M, Parent A. The fate of striatal dopaminergic neurons in Parkinson's disease and Huntington's chorea. Brain. 2007; 130:222-232. [PubMed: 17142832]

Ibanez-Sandoval O, Tecuapetla F, Unal B, Shah F, Koos T, Tepper JM. Electrophysiological and morphological characteristics and synaptic connectivity of tyrosine hydroxylase-expressing neurons in adult mouse striatum. J Neurosci. 2010; 30:6999-7016. [PubMed: 20484642] 
Ilyin VI, Whittemore ER, Guastella J, Weber E, Woodward RM. Subtype-selective inhibition of Nmethyl-D-aspartate receptors by haloperidol. Mol Pharmacol. 1996; 50:1541-1550. [PubMed: 8967976]

Jahanshahi A, Vlamings R, Kaya AH, Lim LW, Janssen ML, Tan S, Visser-Vandewalle V, Steinbusch HW, Temel Y. Hyperdopaminergic status in experimental Huntington disease. J Neuropathol Exp Neurol. 2010; 69:910-917. [PubMed: 20720506]

Jahanshahi A, Vlamings R, van Roon-Mom WM, Faull RL, Waldvogel HJ, Janssen ML, Yakkioui Y, Zeef DH, Kocabicak E, Steinbusch HW, Temel Y. Changes in brainstem serotonergic and dopaminergic cell populations in experimental and clinical Huntington's disease. Neuroscience. 2013; 238:71-81. [PubMed: 23403175]

Jakel RJ, Maragos WF. Neuronal cell death in Huntington's disease: a potential role for dopamine. Trends Neurosci. 2000; 23:239-245. [PubMed: 10838590]

Johnson MA, Rajan V, Miller CE, Wightman RM. Dopamine release is severely compromised in the R6/2 mouse model of Huntington's disease. Journal of neurochemistry. 2006; 97:737-746. [PubMed: 16573654]

Joshi PR, Wu NP, Andre VM, Cummings DM, Cepeda C, Joyce JA, Carroll JB, Leavitt BR, Hayden MR, Levine MS, Bamford NS. Age-dependent alterations of corticostriatal activity in the YAC128 mouse model of Huntington disease. J Neurosci. 2009; 29:2414-2427. [PubMed: 19244517]

Kalivas PW, Duffy P, Barrow J. Regulation of the mesocorticolimbic dopamine system by glutamic acid receptor subtypes. J Pharmacol Exp Ther. 1989; 251:378-387. [PubMed: 2552079]

Kihara T, Shimohama S, Sawada H, Honda K, Nakamizo T, Kanki R, Yamashita H, Akaike A. Protective effect of dopamine D2 agonists in cortical neurons via the phosphatidylinositol 3 kinase cascade. Journal of neuroscience research. 2002; 70:274-282. [PubMed: 12391586]

Kish SJ, Shannak K, Hornykiewicz O. Elevated serotonin and reduced dopamine in subregionally divided Huntington's disease striatum. Ann Neurol. 1987; 22:386-389. [PubMed: 2445259]

Klawans HC, Paulson GW, Barbeau A. Predictive test for Huntington's chorea. Lancet. 1970; 2:11851186. [PubMed: 4098454]

Kornhuber J, Kim JS, Kornhuber ME, Kornhuber HH. The cortico-nigral projection: reduced glutamate content in the substantia nigra following frontal cortex ablation in the rat. Brain research. 1984; 322:124-126. [PubMed: 6151416]

Kowall NW, Ferrante RJ, Martin JB. Patterns of cell loss in Huntington's disease. Trends Neurosci. 1987; 10:24-29.

Kung VW, Hassam R, Morton AJ, Jones S. Dopamine-dependent long term potentiation in the dorsal striatum is reduced in the R6/2 mouse model of Huntington's disease. Neuroscience. 2007; 146:1571-1580. [PubMed: 17478055]

Lao CL, Lu CS, Chen JC. Dopamine D3 receptor activation promotes neural stem/progenitor cell proliferation through AKT and ERK1/2 pathways and expands type-B and -C cells in adult subventricular zone. Glia. 2013; 61:475-489. [PubMed: 23322492]

Lawrence AD, Hodges JR, Rosser AE, Kershaw A, ffrench-Constant C, Rubinsztein DC, Robbins TW, Sahakian BJ. Evidence for specific cognitive deficits in preclinical Huntington's disease. Brain: a journal of neurology. 1998; 121 (Pt 7):1329-1341. [PubMed: 9679784]

Lobo MK, Yeh C, Yang XW. Pivotal role of early B-cell factor 1 in development of striatonigral medium spiny neurons in the matrix compartment. Journal of neuroscience research. 2008; 86:2134-2146. [PubMed: 18338816]

Mangiarini L, Sathasivam K, Seller M, Cozens B, Harper A, Hetherington C, Lawton M, Trottier Y, Lehrach H, Davies SW, Bates GP. Exon 1 of the HD gene with an expanded CAG repeat is sufficient to cause a progressive neurological phenotype in transgenic mice. Cell. 1996; 87:493506. [PubMed: 8898202]

Massouh M, Wallman MJ, Pourcher E, Parent A. The fate of the large striatal interneurons expressing calretinin in Huntington's disease. Neurosci Res. 2008; 62:216-224. [PubMed: 18801393]

Maurice N, Deniau JM, Glowinski J, Thierry AM. Relationships between the prefrontal cortex and the basal ganglia in the rat: physiology of the cortico-nigral circuits. J Neurosci. 1999; 19:4674-4681. [PubMed: 10341265] 
McGeer PL, McGeer EG. Enzymes associated with the metabolism of catecholamines, acetylcholine and gaba in human controls and patients with Parkinson's disease and Huntington's chorea. J Neurochem. 1976; 26:65-76. [PubMed: 3629]

McLaughlin BA, Nelson D, Erecinska M, Chesselet MF. Toxicity of dopamine to striatal neurons in vitro and potentiation of cell death by a mitochondrial inhibitor. Journal of neurochemistry. 1998; 70:2406-2415. [PubMed: 9603205]

Meltzer LT, Christoffersen CL, Serpa KA. Modulation of dopamine neuronal activity by glutamate receptor subtypes. Neurosci Biobehav Rev. 1997; 21:511-518. [PubMed: 9195610]

Mestre TA, Ferreira JJ. An evidence-based approach in the treatment of Huntington's disease. Parkinsonism Relat Disord. 2012; 18:316-320. [PubMed: 22177624]

Milner AJ, Cummings DM, Spencer JP, Murphy KP. Bi-directional plasticity and age-dependent longterm depression at mouse CA3-CA1 hippocampal synapses. Neurosci Lett. 2004; 367:1-5. [PubMed: 15308285]

Milnerwood AJ, Cummings DM, Dallerac GM, Brown JY, Vatsavayai SC, Hirst MC, Rezaie P, Murphy KP. Early development of aberrant synaptic plasticity in a mouse model of Huntington's disease. Hum Mol Genet. 2006; 15:1690-1703. [PubMed: 16600988]

Mochel F, Durant B, Durr A, Schiffmann R. Altered dopamine and serotonin metabolism in motorically asymptomatic R6/2 mice. PLoS One. 2011; 6:e18336. [PubMed: 21483838]

Murase S, Grenhoff J, Chouvet G, Gonon FG, Svensson TH. Prefrontal cortex regulates burst firing and transmitter release in rat mesolimbic dopamine neurons studied in vivo. Neurosci Lett. 1993; 157:53-56. [PubMed: 7901810]

Murphy KP, Carter RJ, Lione LA, Mangiarini L, Mahal A, Bates GP, Dunnett SB, Morton AJ. Abnormal synaptic plasticity and impaired spatial cognition in mice transgenic for exon 1 of the human Huntington's disease mutation. J Neurosci. 2000; 20:5115-5123. [PubMed: 10864968]

Nieoullon A, Cheramy A, Glowinski J. Release of dopamine evoked by electrical stimulation of the motor and visual areas of the cerebral cortex in both caudate nuclei and in the substantia nigra in the cat. Brain research. 1978; 145:69-83. [PubMed: 638784]

Orth M, Schippling S, Schneider SA, Bhatia KP, Talelli P, Tabrizi SJ, Rothwell JC. Abnormal motor cortex plasticity in premanifest and very early manifest Huntington disease. Journal of neurology, neurosurgery, and psychiatry. 2010; 81:267-270.

Ortiz AN, Kurth BJ, Osterhaus GL, Johnson MA. Dysregulation of intracellular dopamine stores revealed in the R6/2 mouse striatum. Journal of neurochemistry. 2010; 112:755-761. [PubMed: 19929911]

Ortiz AN, Osterhaus GL, Lauderdale K, Mahoney L, Fowler SC, von Horsten S, Riess O, Johnson MA. Motor function and dopamine release measurements in transgenic Huntington's disease model rats. Brain research. 2012; 1450:148-156. [PubMed: 22418060]

Oyanagi K, Takeda S, Takahashi H, Ohama E, Ikuta F. A quantitative investigation of the substantia nigra in Huntington's disease. Ann Neurol. 1989; 26:13-19. [PubMed: 2528318]

Paoletti P, Vila I, Rife M, Lizcano JM, Alberch J, Gines S. Dopaminergic and glutamatergic signaling crosstalk in Huntington's disease neurodegeneration: the role of p25/cyclin-dependent kinase 5. J Neurosci. 2008; 28:10090-10101. [PubMed: 18829967]

Parent M, Bedard C, Pourcher E. Dopaminergic innervation of the human subventricular zone: a comparison between Huntington's chorea and Parkinson's disease. Am J Neurodegener Dis. 2013; 2:221-227. [PubMed: 24093085]

Petersen A, Puschban Z, Lotharius J, NicNiocaill B, Wiekop P, O’Connor WT, Brundin P. Evidence for dysfunction of the nigrostriatal pathway in the R6/1 line of transgenic Huntington's disease mice. Neurobiology of disease. 2002; 11:134-146. [PubMed: 12460553]

Petersen AA, Larsen KE, Behr GG, Romero N, Przedborski S, Brundin P, Sulzer D. Brain-derived neurotrophic factor inhibits apoptosis and dopamine-induced free radical production in striatal neurons but does not prevent cell death. Brain Res Bull. 2001; 56:331-335. [PubMed: 11719268]

Phillips W, Shannon KM, Barker RA. The current clinical management of Huntington's disease. Mov Disord. 2008; 23:1491-1504. [PubMed: 18581443]

Pifl C, Pichler L, Kobinger W, Hornykiewicz O. The dopamine autoreceptor agonist, B-HT 920, preferentially reduces brain dopamine release in vivo: biochemical indices of brain dopamine, 
noradrenaline and serotonin in ventriculocisternal perfusates in the cat. European journal of pharmacology. 1988; 153:33-44. [PubMed: 2463928]

Porritt MJ, Batchelor PE, Hughes AJ, Kalnins R, Donnan GA, Howells DW. New dopaminergic neurons in Parkinson's disease striatum. Lancet. 2000; 356:44-45. [PubMed: 10892768]

Pouladi MA, Stanek LM, Xie Y, Franciosi S, Southwell AL, Deng Y, Butland S, Zhang W, Cheng SH, Shihabuddin LS, Hayden MR. Marked differences in neurochemistry and aggregates despite similar behavioural and neuropathological features of Huntington disease in the full-length BACHD and YAC128 mice. Hum Mol Genet. 2012; 21:2219-2232. [PubMed: 22328089]

Prensa L, Cossette M, Parent A. Dopaminergic innervation of human basal ganglia. J Chem Neuroanat. 2000; 20:207-213. [PubMed: 11207419]

Reiner A, Shelby E, Wang H, Demarch Z, Deng Y, Guley NH, Hogg V, Roxburgh R, Tippett LJ, Waldvogel HJ, Faull RL. Striatal parvalbuminergic neurons are lost in Huntington's disease: implications for dystonia. Mov Disord. 2013; 28:1691-1699. [PubMed: 24014043]

Richardson EP Jr. Third Dorothy S. Russell memorial lecture. Huntington's disease: some recent neuropathological studies. Neuropathol Appl Neurobiol. 1990; 16:451-460. [PubMed: 2151398]

Richfield EK, O'Brien CF, Eskin T, Shoulson I. Heterogeneous dopamine receptor changes in early and late Huntington's disease. Neurosci Lett. 1991; 132:121-126. [PubMed: 1838580]

Sandstrom MI, Sally Steffes-Lovdahl S, Jayaprakash N, Wolfram-Aduan A, Dunbar GL. Early Dysfunction of Neural Transmission and Cognitive Processing in Huntington's Disease. 2010

Sapp E, Kegel KB, Aronin N, Hashikawa T, Uchiyama Y, Tohyama K, Bhide PG, Vonsattel JP, DiFiglia M. Early and progressive accumulation of reactive microglia in the Huntington disease brain. J Neuropathol Exp Neurol. 2001; 60:161-172. [PubMed: 11273004]

Sawada H, Ibi M, Kihara T, Urushitani M, Akaike A, Kimura J, Shimohama S. Dopamine D2-type agonists protect mesencephalic neurons from glutamate neurotoxicity: mechanisms of neuroprotective treatment against oxidative stress. Ann Neurol. 1998; 44:110-119. [PubMed: 9667598]

Sesack SR, Carr DB. Selective prefrontal cortex inputs to dopamine cells: implications for schizophrenia. Physiol Behav. 2002; 77:513-517. [PubMed: 12526992]

Shen S, Pu J, Lang B, McCaig CD. A zinc finger protein Zfp521 directs neural differentiation and beyond. Stem Cell Res Ther. 2011; 2:20. [PubMed: 21539723]

Slow EJ, van Raamsdonk J, Rogers D, Coleman SH, Graham RK, Deng Y, Oh R, Bissada N, Hossain SM, Yang YZ, Li XJ, Simpson EM, Gutekunst CA, Leavitt BR, Hayden MR. Selective striatal neuronal loss in a YAC128 mouse model of Huntington disease. Hum Mol Genet. 2003; 12:1555-1567. [PubMed: 12812983]

Spargo E, Everall IP, Lantos PL. Neuronal loss in the hippocampus in Huntington's disease: a comparison with HIV infection. Journal of neurology, neurosurgery, and psychiatry. 1993; 56:487-491.

Spokes EG. Neurochemical alterations in Huntington's chorea: a study of post-mortem brain tissue. Brain: a journal of neurology. 1980; 103:179-210. [PubMed: 6102490]

Suzuki M, Desmond TJ, Albin RL, Frey KA. Vesicular neurotransmitter transporters in Huntington's disease: initial observations and comparison with traditional synaptic markers. Synapse. 2001; 41:329-336. [PubMed: 11494403]

Tang TS, Chen X, Liu J, Bezprozvanny I. Dopaminergic signaling and striatal neurodegeneration in Huntington's disease. J Neurosci. 2007; 27:7899-7910. [PubMed: 17652581]

Tedroff J, Ekesbo A, Sonesson C, Waters N, Carlsson A. Long-lasting improvement following (-)OSU6162 in a patient with Huntington's disease. Neurology. 1999; 53:1605-1606. [PubMed: 10534281]

Thiruvady DR, Georgiou-Karistianis N, Egan GF, Ray S, Sritharan A, Farrow M, Churchyard A, Chua P, Bradshaw JL, Brawn TL, Cunnington R. Functional connectivity of the prefrontal cortex in Huntington's disease. Journal of neurology, neurosurgery, and psychiatry. 2007; 78:127-133.

Usdin MT, Shelbourne PF, Myers RM, Madison DV. Impaired synaptic plasticity in mice carrying the Huntington's disease mutation. Hum Mol Genet. 1999; 8:839-846. [PubMed: 10196373] 
van der Hiele K, Jurgens CK, Vein AA, Reijntjes RH, Witjes-Ane MN, Roos RA, van Dijk G, Middelkoop HA. Memory activation reveals abnormal EEG in preclinical Huntington's disease. Mov Disord. 2007; 22:690-695. [PubMed: 17266047]

Van Kampen JM, Hagg T, Robertson HA. Induction of neurogenesis in the adult rat subventricular zone and neostriatum following dopamine D3 receptor stimulation. Eur J Neurosci. 2004; 19:2377-2387. [PubMed: 15128392]

van Oostrom JC, Dekker M, Willemsen AT, de Jong BM, Roos RA, Leenders KL. Changes in striatal dopamine D2 receptor binding in pre-clinical Huntington's disease. Eur J Neurol. 2009; 16:226231. [PubMed: 19138335]

Venuto CS, McGarry A, Ma Q, Kieburtz K. Pharmacologic approaches to the treatment of Huntington's disease. Mov Disord. 2012; 27:31-41. [PubMed: 21997232]

von Horsten S, et al. Transgenic rat model of Huntington's disease. Hum Mol Genet. 2003; 12:617624. [PubMed: 12620967]

Vonsattel JP, Keller C, Del Pilar Amaya M. Neuropathology of Huntington's disease. Handb Clin Neurol. 2008a; 89:599-618. [PubMed: 18631782]

Vonsattel JP, Keller C, Pilar Amaya MD. Neuropathology of Huntington's Disease. Handb Clin Neurol. 2008b; 89:599-618. [PubMed: 18631782]

Vonsattel JP, Myers RH, Stevens TJ, Ferrante RJ, Bird ED, Richardson EP Jr. Neuropathological classification of Huntington's disease. J Neuropathol Exp Neurol. 1985; 44:559-577. [PubMed: 2932539]

Walker AG, Miller BR, Fritsch JN, Barton SJ, Rebec GV. Altered information processing in the prefrontal cortex of Huntington's disease mouse models. J Neurosci. 2008; 28:8973-8982. [PubMed: 18768691]

Wang J, O'Donnell P. D(1) dopamine receptors potentiate nmda-mediated excitability increase in layer V prefrontal cortical pyramidal neurons. Cereb Cortex. 2001; 11:452-462. [PubMed: 11313297]

Weeks RA, Piccini P, Harding AE, Brooks DJ. Striatal D1 and D2 dopamine receptor loss in asymptomatic mutation carriers of Huntington's disease. Ann Neurol. 1996; 40:49-54. [PubMed: 8687191]

Williams GV, Castner SA. Under the curve: critical issues for elucidating D1 receptor function in working memory. Neuroscience. 2006; 139:263-276. [PubMed: 16310964]

Wu J, Tang T, Bezprozvanny I. Evaluation of clinically relevant glutamate pathway inhibitors in in vitro model of Huntington's disease. Neurosci Lett. 2006; 407:219-223. [PubMed: 16959411]

Yohrling, GJt; Jiang, GC.; DeJohn, MM.; Miller, DW.; Young, AB.; Vrana, KE.; Cha, JH. Analysis of cellular, transgenic and human models of Huntington's disease reveals tyrosine hydroxylase alterations and substantia nigra neuropathology. Brain Res Mol Brain Res. 2003; 119:28-36. [PubMed: 14597227]

Zeron MM, Hansson O, Chen N, Wellington CL, Leavitt BR, Brundin P, Hayden MR, Raymond LA. Increased sensitivity to N-methyl-D-aspartate receptor-mediated excitotoxicity in a mouse model of Huntington's disease. Neuron. 2002; 33:849-860. [PubMed: 11906693] 